\title{
AFLATOXICOSIS IN POULTRY: \\ 1- EFFICACY OF HYDRATED SODIUM CALCIUM ALUMINOSILICATE AND YEAST CELL WALL TO AMELIORATE THE ADVERSE EFFECTS OF AFLATOXIN ON BROILER PERFORMANCE \\ Shebl, M.A.; H.F.A. Motawe; T. M. Yehia and Amal A. Abo Hagger Regional Center for Food and Feed, Agric. Res. Center, Giza, Egypt.
}

\begin{abstract}
Hydrated Sodium Calcium Aluminosilicate (HSCAS) and Yeast (Saccharomyces cerevisiae) cell wall (YCW) were evaluated for their ability to reduce the deleterious effects of aflatoxin (AFT) on broiler performance. They were incorporated singly or in combination into a diet containing total AFT $211.88 \mu \mathrm{g} / \mathrm{kg}$ feed . No significant changes was recorded in all tested parameters ,body weight ( BW ), body weight gain ( BWG), feed intake (FI) and feed conversion ( FC) ratio during starter period. In growing period, treated groups showing significant elevation in some recorded parameter, that in contrast with each other or with control groups. In finisher periods, however no detectable pattern for changes was recorded, but the group which treated with HSCAS only showing significant depletion in both BWG and $\mathrm{FI}$, while that treated with it in AFT- contaminated diet showing significant elevation . The same significant elevation was recorded in BW ,BWG and FI for groups which treated with YCW, while liver weight of this groups was significantly decreased in relation to other groups. The highest mortality rate was recorded in group treated with AFT only, and that which treated with AFT and YCW . The highest level of aflatoxin residue in litter of broiler was recorded in litter of group which treated with HSCAS singly, while the lowest was in group treated with YCW only. The levels of microelements $\mathrm{Al}, \mathrm{As}, \mathrm{Cd}, \mathrm{Pd}, \mathrm{Se}, \mathrm{Cu}, \mathrm{Fe}, \mathrm{Mn}, \mathrm{Zn}$ and macro-elements $\mathrm{k}, \mathrm{Na}, \mathrm{Mg}$ in broiler litter of different tested groups were also affected. The present study concluded that, no clear improvements in the tested parameters were recorded after the the contaminated diets were incorporated with the tested dose of HSCAS and YCW, singly or in combination, during aflatoxicosis. Also, in part, focused the unwanted behavioral of adsorbents in animal production, and submitted that the using of this materials in animal feed must be restricted, because of its unknown undesired effects, as well as its indirect dangerous effect in livestock.
\end{abstract}

\section{INTRODUCTION}

Aflatoxins (AFT) constitute a group of heterocyclic
metabolites synthesized mainly by Aspergillus flavus, Aspergillus
parasiticus and Aspergillus nomius. At least 18 different AFT have been
identified, including AFB $B_{1}, B_{2}, G_{1}, G_{2}, B_{2 a}, G_{2 a}, M_{1}, M_{2}, P_{1}, Q_{1}$, aflatoxicol $A$
and $B, D_{1}$, of which only the first 4 are found naturally; the others are
metabolic products of animal or microbial systems or are produced
spontaneously in response to environmental chemical products (Cole and
Cox, 1981). Aflatoxins present in contaminated feed are rapidly
absorbed in the small intestine, affecting mainly the liver, leading to metabolic
disorders. Fat degeneration and proliferation of biliary ducts induce bloody
changes generally seen as the increase in hepatic enzyme activity,


coagulopathies, and reduction in protein production (Fernandez et al., 1995). Many production parameters can be affected by aflatoxin poisoning, such as BW gain, feed consumption, plasmatic proteins, cholesterol, and mortality rate (Lanza et al., 1980; Giambrone et al. 1985; Quist et al., 2000). Aflatoxin sensibility varies among species. A wide variation exists in species susceptibility to AFB1 hepatocarcinogenesis. Fish and poultry known to be extremely sensitive to AFB1, responded to doses as low as $15-30 \mu \mathrm{g} / \mathrm{kg}$ ( Rawal et al. 2010). In birds, Turkey and Geese are the most sensitive to aflatoxins (Arafa et al., 1981). Toxic effects of AFT commonly observed in animals include poor absorption of nutrients sometimes leading to death, reduced tissue integrity, lower growth rates and poor feed conversion, reduced immune response, reproductive problems in males and females, and increasing sensitivity to extreme temperatures (Leeson et al., 1995; Davegowda and Murthy, 2005).

Aflatoxins result in economic losses to poultry industry from reductions in growth rate, hatchability, feed efficiency and immunity towards diseases (Richard et al., 1986; Coulombe, 1993). According to a report by Council for Agricultural Science and Technology, USA, losses due to AFT to the United States poultry industry exceeded $\$ 143$ million annually (CAST, 1989). A recent study reported annual crop losses of $\$ 932$ million due to mycotoxin contamination and additional - 302 -losses of $\$ 466$ million in efforts to prevent or reduce contamination (CAST, 2003).

In the past $20 \mathrm{yr}$, prevalence of high range of aflatoxin (AFT), mainly B1, in some Egyptian food and feed stuffs are common (Badria, 1996; Selim et al., 1996; El-Tahan et al ., 2000).In growing countries, control of aflatoxin often means balancing between a certain risk of starvation against an uncertain risk of cancer (Badria, 1996). When aflatoxin prevention fails, removal or destruction must be considered if the product is to be used for food or feed purposes (Park, 1995). At present, one of the more famous approaches to solve the proplem of AFT incidence is the use of adsorbents. Many materials were used in this field, the most famous are Hydrated Sodium Calcium Aluminosilicate (HSCAS) and Yeast (Saccharomyces cerevisiae) cell wall (YCW) . Effect of both in poultry have been reported (Ledoux et al., 1999 ; Stanley et al., 2000; Zhang et al., 2005). Major advantages of these adsorbents are that they are relatively inexpensive. It should be noted that most of these products haven't been approved for commercial use by FDA (Battacone et al., 2009 ).

The objectives of this study were to evaluate the efficacy of using HSCAS and YCW singly or in combination to ameliorate aflatoxicosis in broiler performance.

\section{MATERIALS AND METHODS}

\section{Animals:}

Total number of 224 one-day old unsexed Ross chicks were obtained from a commercial hatchery and were randomly distributed among eight treated groups ( each of 28 chicks), in a washed fumigated batteries . 
Groups:

Group 1 : control -v (fed on AFT free diet )

Group 2 : control -V + HSCAS

Group 3 : control $-v+Y^{*} W^{*}$

Group 4 : control -V + HSCAS + YCW

Group $5:$ control $+\mathrm{V}\left(\mathrm{AFT}{ }^{* * *}\right.$ contaminated diet $)$

Group 6 : control +V + HSCAS

Group 7 : control +V + YCW

Group 8 : control +v + HSCAS + YCW

* HSCAS : Hydrated Sodium Calcium Aluminosilicate $100 \%$ (origin - USA ) Regesterated in Ministry of Agriculture (No. : 1661 -26/8/2008), and given in a dose $2 \mathrm{~kg} /$ ton feed.

** YCW : Yeast (Saccharomyces cerevisiae) cell wall $98 \%$ (origin - USA) contains : Mannan - oligosaccharides $10 \%$ Beta - Glucans $24 \%$ Regesterated in Ministry of Agriculture (No. : 9764 -18/9/2007) , under commercial name ALPHAMUNE and given in a dose $0.5 \mathrm{~kg} /$ ton feed.

${ }^{* * *}$ AFT :(Aflatoxin ) tested dose was $\left(50 B_{1}+18.85 B_{2}+140.3 \mathrm{G}_{1}+3 \mathrm{G}_{2}\right) \mu \mathrm{g}$, give a total AFT $211.88 \mu \mathrm{g} / \mathrm{kg}$ feed.

Feed and water were provided ad-libitum. Feed was formulated in Regional center for Food and Feed to be isonitrogenous, isocaloric and aflatoxin-free. Light was provided $24 \mathrm{hrs}$ daily through out the period( 40 days). Temperature keept to the required during brooding period.

The chicks were weighed individually through the experiment and body weight ( BW ) was recorded, and body weight gain ( BWG) was calculated . Feed intake $(\mathrm{FI})$ was recorded throughout the periods on a group basis. Feed intake and feed conversion ( FC) ratio ( unit feed / unit gain ) were calculated. Litter from each group was collected, weighed, and dried.

Aflatoxin production and assessment:

Aflatoxin production was carried out according to Davis et al., (1966) using liquid yeast medium and Aspergillus Flavus strain (NRRL 3145). The media which contain detectable amount of aflatoxin was mixed well with the basal diet to get the aflatoxin - contaminated diet.

Aflatoxin in liquid medium, diet, tissues and litter were determined according to Roos et al.,(1997) and A.O.A.C (2005) using HPLC technique (

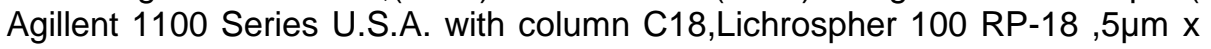
$25 \mathrm{~cm})$.

\section{Micro- and macro-elements assessment:}

Assessment of micro-elements $\mathrm{Al}, \mathrm{As}, \mathrm{Cd}, \mathrm{Pd}, \mathrm{Se}, \mathrm{Cu}, \mathrm{Fe}, \mathrm{Mn}$, $\mathrm{Zn}$ and macro-elements $\mathrm{k}, \mathrm{Na}, \mathrm{Mg}$ were determined in both breast and thigh muscles, and liver tissues according to Agemian et al., (1980), using ICP- OE Plasma, optima DV 2000.

Statistical analysis :

Statistical analysis was carried out according to Heath (1995) in one way analysis of variance. Data represented as means $\pm S D$, for $n=3$. The difference was considered significant only at P. $<0.05$. 
Shebl, M.A. et al.

\section{RESULTS AND DISCUSSION}

The effect of feeding aflatoxin contaminated diet ,singly or in combination with the detoxificated tested materials, on broiler performance are illustrated in Tables (1-4) and Figures( 1-4).

As it is evident from Table (1) and Figure (1), which represented the effect during starter period, no significant changes was recorded, except group 8 (control +V + HSCAS + YCW ) which showing significant depression in all tested parameter in contrast with most of other groups .

Table(1) \& Fig.(1) : Effect of Aflatoxin and tested materials on Broiler performance ( starter period) of different groups

\begin{tabular}{|c|c|c|c|c|}
\hline \multirow{2}{*}{ Groups } & \multicolumn{4}{|c|}{ Performance parameter } \\
\cline { 2 - 5 } & $\mathbf{B W}$ & BWG & FI & FC \\
\hline $\mathbf{1}$ & $334.44 \pm 15.03^{8}$ & $287 \pm 8.16$ & $354 \pm 12.77^{1,8}$ & $1.223 \pm .05^{8}$ \\
\hline $\mathbf{2}$ & $325.44 \pm 21.77$ & $289.67 \pm 8.39$ & $351.67 \pm 7.64^{8}$ & $1.247 \pm .064^{8}$ \\
\hline $\mathbf{3}$ & $330 \pm 26.45^{8}$ & $310.33 \pm 17.04^{5,8}$ & $249.67 \pm 8.96^{8}$ & $1.17 \pm .053$ \\
\hline $\mathbf{4}$ & $346.33 \pm 14.84^{8}$ & $313.33 \pm 25.17^{5,8}$ & $360 \pm 10^{6,7,8}$ & $1.173 \pm .049$ \\
\hline $\mathbf{5}$ & $320 \pm 20^{8}$ & $274.33 \pm 16.77^{3,4,6}$ & $335 \pm 15^{8}$ & $1.183 \pm 0.16$ \\
\hline $\mathbf{6}$ & $344.44 \pm 13.88^{4,5,8}$ & $304.33 \pm 13.65^{5,8}$ & $332 \pm 19.16^{4,8}$ & $1.173 \pm .025$ \\
\hline $\mathbf{7}$ & $343.33 \pm 25.17^{8}$ & $296 \pm 15.01^{8}$ & $327.67 \pm 25.52^{1,4,8}$ & $1.143 \pm .051$ \\
\hline $\mathbf{8}$ & $293 \pm 11.26^{1,3,4,6, /}$ & $263.33 \pm 15.28^{3,4,6, /}$ & $276.67 \pm 15.28^{1,2,3,4,5,6,7}$ & $1.063 \pm .031^{1,2}$ \\
\hline
\end{tabular}

Data expressed as mean $\pm S D$, means within the same column are labeled (superscript no.) with the group(s) no. which they significantly $(p<.05)$ different with it

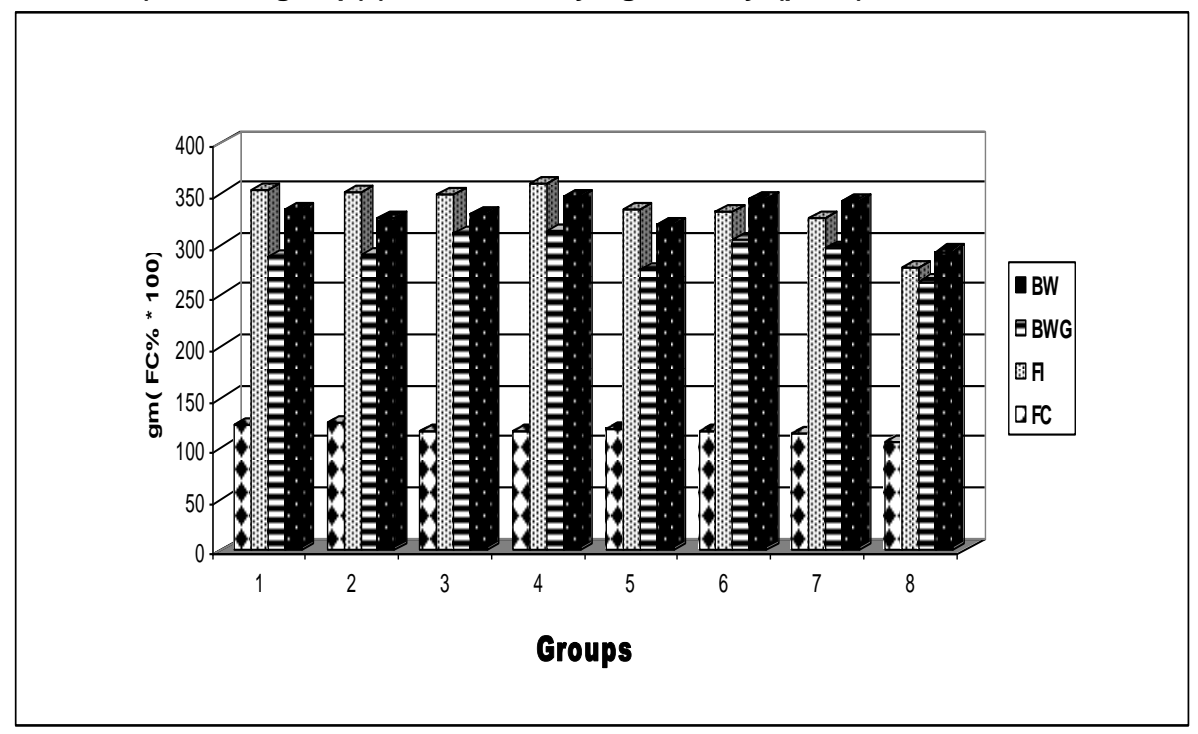

Growing period data were recorded in Table (2) and represented in Figure (2). Data recorded revealed no clear pattern of changes was recorded in this stage in all groups, however, treated groups $(5,6,7,8)$ showing significant elevation in some recorded parameter, that in contrast with each other or with control groups. That elevation was very clear in group 7 in BWG and $\mathrm{FI}$, that in contrast with major of the groups . 
Table(2) \& Fig.(2) : Effect of Aflatoxin and tested materials on Broiler performance ( grower period) of different groups

\begin{tabular}{|c|c|c|c|c|}
\hline \multirow{2}{*}{ Groups } & \multicolumn{4}{|c|}{ Performance parameter } \\
\cline { 2 - 5 } & $\mathbf{B W}$ & $\mathbf{B W G}$ & $\mathbf{F I}$ & FC \\
\hline $\mathbf{1}$ & $1082.81 \pm 30.24$ & $757 \pm 23.388^{5, /}$ & $1413 \pm 14.73^{1,8}$ & $1.84 \pm .095$ \\
\hline $\mathbf{2}$ & $1025.66 \pm 57.9^{4, /}$ & $730 \pm 21.795^{5, /}$ & $1436.667 \pm 20.817^{4,8}$ & $1.833 \pm .049$ \\
\hline $\mathbf{3}$ & $1089 \pm 34.83$ & $744.66 \pm 25^{5,4^{5, /}}$ & $1423 \pm 34.36^{4,8}$ & $1.88 \pm .026^{5,8}$ \\
\hline $\mathbf{4}$ & $1101.667 \pm 44.82^{2}$ & $761.333 \pm 11.02^{5, /}$ & $1402.67 \pm 15^{2,3,7,8}$ & $1.833 \pm .059$ \\
\hline $\mathbf{5}$ & $1099 \pm 33.51$ & $796.667 \pm 33.511^{1,2,3,4,6,8}$ & $1423.67 \pm 15.2^{1,8}$ & $1.75 \pm .04^{3,6}$ \\
\hline $\mathbf{6}$ & $1081.444 \pm 32.14$ & $750.777 \pm 32.14^{5,7}$ & $1421.33 \pm 13.55^{7,8}$ & $1.91 .059^{5,7,8}$ \\
\hline $\mathbf{7}$ & $1107.11 \pm 46.81^{2,8}$ & $803.667 \pm 20.13^{1,2,3,4,6,8}$ & $1450.33 \pm 13.33^{1,4,5,6,8}$ & $1.81 \pm .01^{6}$ \\
\hline $\mathbf{8}$ & $1028.99724 .44^{7}$ & $735.373 \pm 21.891^{5, /}$ & $1335 \pm 16.92^{1,2,3,4,5,6,7}$ & $1.76 \pm .037^{3,6}$ \\
\hline
\end{tabular}

Data expressed as mean $\pm S D$, means within the same column are labeled (superscript no.) with the group $(s)$ no. which they significantly $(p<.05)$ different with it

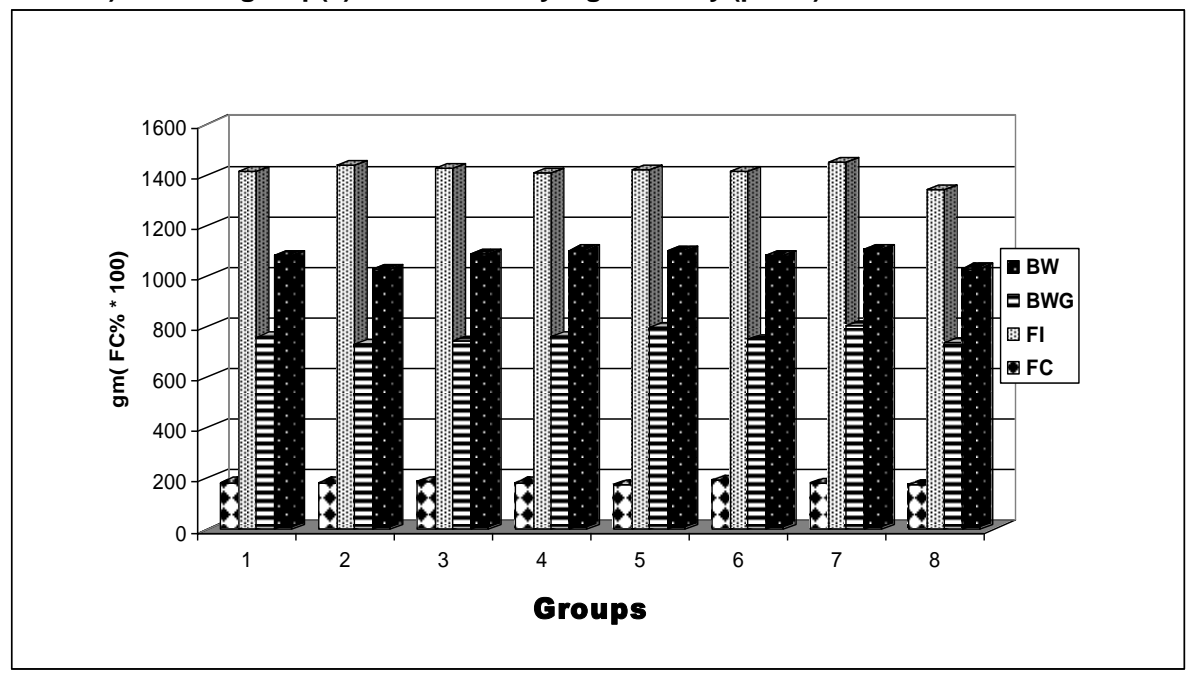

In finisher period (Table 3 and Figure 3), the unspecific changeable pattern was continued, but the most noticeable record was that, no significant change in FC was recorded among all groups. The group 2 which treated with HSCAS only showing significant depletion in both BWG and $\mathrm{FI}$ ratio, while that treated with it in AFT- contaminated diet showing significant elevation. The same significant elevation was recorded in groups 3,7 (which treated with YCW ) in BW ,BWG and FI ratios .

Data calculated for entire period revealed the same pattern of changes as in finisher period. The groups $2,6,8$ which treated with HSCAS singly or in-combination with YCW showing significant depletion in BW, BWG and $\mathrm{FI}$ ratios that in contrast with control groups. In group 7 , which treated with YCW, the previous ratios were significantly elevated.

The main aflatoxin action mechanism is the reduction on the function of liver, primarily inhibition of the synthesis of proteins. The lipidic metabolism is also affected (Hussein and Brasel, 2001) due to the reduction on enzymes synthesis and activity, mainly in chronic exposures. In 1970 Joffe concluded that $6,650 \mathrm{ppb}$ is the minimum aflatoxin dose that can significantly reduce the weight gain in poults during the first 21 days. Hamilton et al. (1972) found 
that $250 \mathrm{ppb}$ is the minimum concentration that can significantly affect BW gain in turkeys. $\mathrm{AFB}_{1}$ in a dose $2500 \mathrm{ppb}$ significantly decreased $\mathrm{BW}$ of 3 weeks old broiler chicks (Scheideler, 1993). Broiler chickens poisoned with $3,000 \mathrm{ppb}$ of aflatoxins showed a reduction of $37 \%$ and $27 \%$ in BW when compared with the control group at 21 and 42 days old respectively (Giacomini et al., 2006). In Growing Local Chickens received a basal diet contaminated with $1000 \mathrm{ppb} \mathrm{AFB}_{1}$, high levels of $\mathrm{AFB}_{1}$ - residues were detected in tissues and liver of it (Hassan , 2006). The same dose reduced BWG of Local Laying Hen (Ali et al. , 2006). In turkeys, Rauber et al.(2007) found that animals received $200 \mathrm{ppb}$ of aflatoxins or more $(500$, and 1,000$)$ had a significant lower weight gain . They added that turkey poults are 3 to 6 times more sensitive to aflatoxins than broilers. All the previous speculation can explain , in part , the insignificant change in performance parameter which recorded herein in control positive group (group 5) and other AFTtreated groups.

Table (3) \& Fig(3): Effect of Aflatoxin and tested materials on Broiler performance ( finisher period) of different groups

\begin{tabular}{|c|c|c|c|c|}
\hline \multirow{2}{*}{ Groups } & \multicolumn{3}{|c|}{ Performance parameter } & FC \\
\cline { 2 - 5 } & $1741 \pm 10.03$ & $622.667 \pm 19.66^{1,2}$ & $1354.667 \pm 12.77^{2,7,8}$ & $2.117 \pm .104$ \\
\hline $\mathbf{1}$ & $1656.333 \pm 31.77^{3,7}$ & $581 \pm 10.15^{1,3,4,5,6,7,8}$ & $1292.333 \pm 10.785^{1,3,4,6,6,7,8}$ & $2.23 \pm .061$ \\
\hline $\mathbf{3}$ & $1766.667 \pm 20.817^{2,4}$ & $649.33 \pm 11.015^{1,2,4,6}$ & $1340 \pm 10^{2,6}$ & $2.046 \pm .056$ \\
\hline $\mathbf{4}$ & $1652.33 \pm 161.37^{3, /}$ & $610 \pm 8.718^{2,3, /}$ & $1356.667 \pm 15.257^{2,7,8}$ & $2.136 \pm .128$ \\
\hline $\mathbf{5}$ & $1733 \pm 34.6$ & $625.333 \pm 21.939^{2}$ & $1345.667 \pm 15.257^{2,6,7}$ & $2.09 \pm .081$ \\
\hline $\mathbf{6}$ & $1726.777 \pm 15.42^{2,4}$ & $611 \pm 16.522^{2,3,7}$ & $1371.667 \pm 10.408^{2,3,5,7,8}$ & $2.163 \pm .148$ \\
\hline $\mathbf{7}$ & $1769.333 \pm 43.143^{2,4}$ & $647.513 \pm 12.238^{2,4,6}$ & $1319.333 \pm 16.773^{1,2,4,5,6}$ & $2.057 \pm .151$ \\
\hline $\mathbf{8}$ & $1663 \pm 28.58$ & $624.333 \pm 12.503^{2}$ & $1324.667 \pm 12.585^{1,2,4,6}$ & $2.1 \pm .1$ \\
\hline
\end{tabular}

Data expressed as mean $\pm S D$, means within the same column are labeled (superscript no.) with the group(s) no. which they significantly $(p<.05)$ different with it

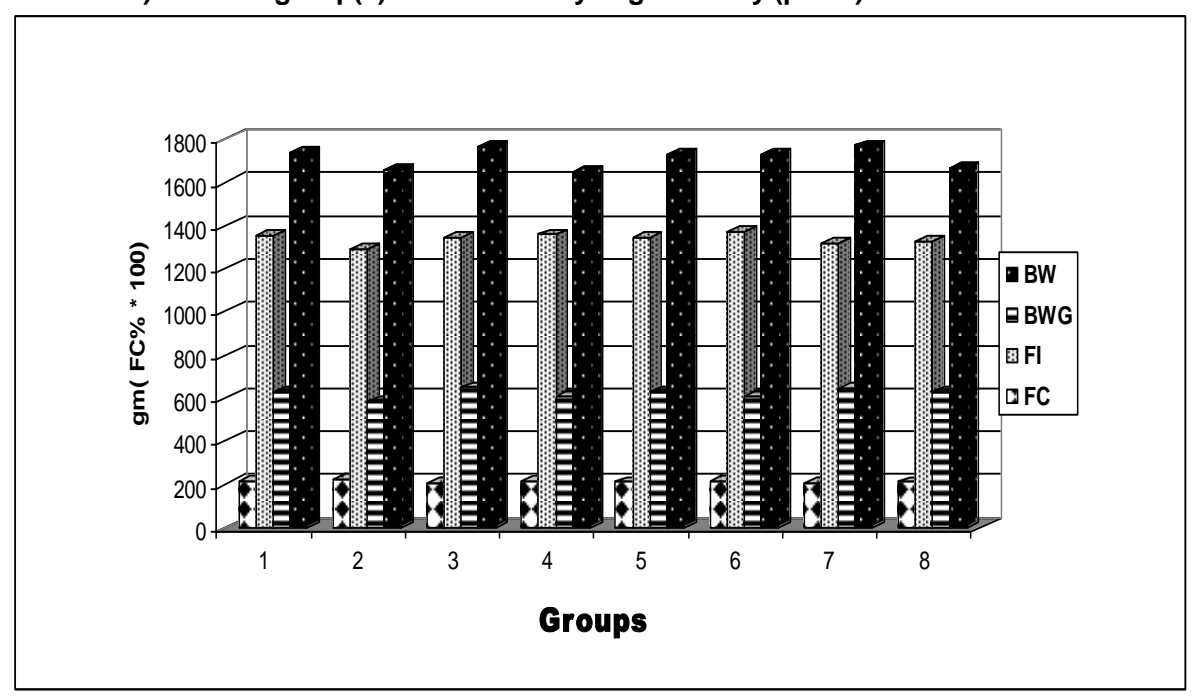


Table(4) \& Fig(4) : Effect of Aflatoxin and tested materials on Broiler performance ( entire period) of different groups

\begin{tabular}{|c|c|c|c|c|}
\hline \multirow[b]{2}{*}{ Groups } & \multicolumn{4}{|c|}{ Performance parameter } \\
\hline & BW & BWG & FI & FC \\
\hline 1 & $1737.077 \pm 15.49^{2,3,5,7,8}$ & $1711.667 \pm 16.07^{2,7,8}$ & $3135.667 \pm 30.92^{2,8}$ & $1.84 \pm .021$ \\
\hline 2 & $1675 \pm 25.9^{1,3,4,5,6,7}$ & $1633.667 \pm 14.041^{1,3,4,5,6,7}$ & $3048.333 \pm 25.044^{1,4,5,8}$ & $1.86 \pm .052$ \\
\hline 3 & $1760 \pm 14.83^{2, r, 8}$ & $1714.67 \pm 13.05^{2,6,8}$ & $3104.333 \pm 19.36^{6,8}$ & $1.826 \pm .055$ \\
\hline 4 & $1752 \pm 17.211^{2,8}$ & $1708.333 \pm 14.33^{2,8}$ & $3142.667 \pm 19.34^{2,8}$ & $1.836 \pm .032$ \\
\hline 5 & $1768 \pm 15.56^{2,8}$ & $1721.667 \pm 13.522^{2,6,8}$ & $3120.218 \pm 18.301^{2,8}$ & $1.84 \pm .044$ \\
\hline 6 & $1726.883 \pm 10.265^{2,3,1,8}$ & $1688.041 \pm 13.042^{2,3,7,8}$ & $3143.443 \pm 15.131^{3,8}$ & $1.85 .056^{\prime}$ \\
\hline 7 & $1784.667 \pm 15.111^{1,2,5,8}$ & $1745 \pm 13.228^{2,4,6,8}$ & $3100.11 \pm 19.83^{8}$ & $1.77 \pm .023^{1,2,6}$ \\
\hline 8 & $1628.997 \pm 10.503^{\prime}$ & $1625.333 \pm 21.961^{1,3,4,5,6,7}$ & $2932 \pm 27.7^{1,2,3,4,5,6,7}$ & $1.8 \pm .05$ \\
\hline
\end{tabular}

Data expressed as mean $\pm S D$, means within the same column are labeled (superscript no.) with the group(s) no. which they significantly $(p<.05)$ different with it

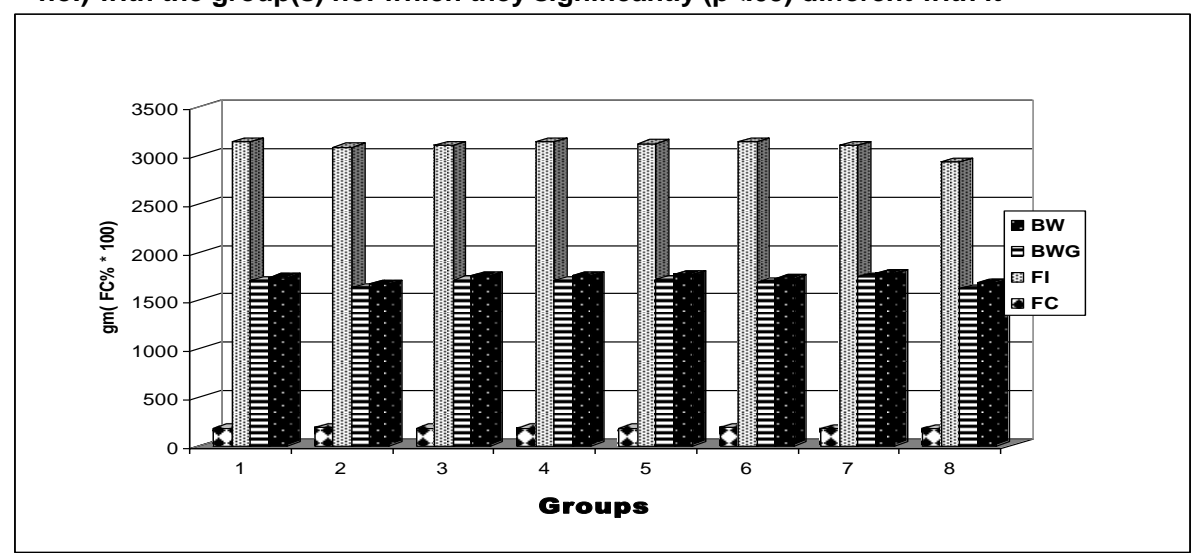

In the present study, the addition of both detoxifier materials to the contaminated diet induced some unexpected negative changes in broiler performance.

Hydrated Aluminosilicates of alkali and alkaline earth cations, having infinite, three -dimensional structure . they are further characterized by an ability to lose and gain water reversibly and to exchange constituent cations ( Mumpton and Fishman , 1977). Bonding between AFT and Aluminosilicates appears to be in the furan rings. Other possible bonding is with the two oxygen in the coumarin ring of AFT and interlayer cations or their associated water molecules. Evidence of octahedral $\mathrm{Fe}$ in smectite and amorphous silica in the clays both indicate greater AFT adsorption potential. Other smectites with spectral absorption indicating predominantly $\mathrm{Al}$ in the octahedral positions adsorbed less $\mathrm{AfB}_{1}$ (Tenorio Arvide et al., 2008 ).The binding ability mainly appear to be $\mathrm{pH}$-dependant ( Ledoux et al., 1999) .

Saccharomyces cerevisiae, yeast cell wall (YCW), components have been used in animal feeding since the last decades (Hooge, 2004; Rosen, 2007). Their inclusion in broiler diets has resulted in improvements of animal productivity, which was attributed to physiological effects on intestinal digestive mucosa (Santin et al., 2001; Zhang et al., 2005; Baurhoo et al., 2007). However, the mode of action of YCW products in broiler chicken diets is not well understood and the characteristics of YCW products have been poorly defined. Typically, commercial YCW are composed of 30 to $60 \%$ 
polysaccharides ( 15 to $30 \%$ of $\beta-1,3 / 1,6$-glucan and 15 to $30 \%$ of mannan sugar polymers), 15 to $30 \%$ proteins, 5 to $20 \%$ lipids, and no more than $5 \%$ of chitin (Aguilar-Uscanga and François, 2003; Eurasyp, 2007). Most of the protein is linked to the mannanoligosaccharides (MOS) and is referred to as the mannoprotein complex. In the digestive tract of animals, MOS present in YCW could act as high-affinity legends, with the potential benefit of offering a competitive binding site for pathogenic bacteria mannose-specific type-1 fimbriae (Spring et al., 2000). In lactating caws , Battacone et al.,( 2009) cited that the addition of a yeast that was not specifically manufactured as a mycotoxin-sequestering agent did not reduce the transfer of AFM1 from feed into milk.

In the present investigation, It is clear that the low tested dose of aflatoxin (211.88 ppb) didn't significantly affect the tested performance parameters. The addition of HSCAS and YCW didn't improve feed efficiency, where the groups which treated with HSCAS singly or in-combination with YCW in AFT-contaminated diet showing significant depletion in BW, BWG and $\mathrm{FI}$ ratios, that in contrast with control groups. The previous ratios significantly elevated in the group treated with YCW in AFT-contaminated diet. The reason for this unexpected action is unknown but may be due to difference in strain of chicken, duration of feeding, type of silicate , composition of the basal diet, levels of sub-clinical disease, or other factors. Some or all of these factors plus others unknown factors could possibly contribute to the unexpected observed action.

The effect of feeding aflatoxin contaminated diet, singly or in combination with the detoxificated tested materials, on broiler liver weight and mortality rate of different groups are illustrated in Table (5) and Figure (5). Data recorded revealed that liver weights of groups 3 (control $-\mathrm{V}+\mathrm{YCW}$ ) $, 5($ control $+v e), 7$ (control $+v+Y C W$ ) significantly decreased in relation to other remaining groups. Two of the previous groups $(3,7)$ were treated with YCW ( without and with AFT ) , while the remaining group is the group which treated with AFT only. The depletion rate was about $23 \%$. Data recorded revealed also no mortality in the first three groups. On the other hand, the highest mortality rate was recorded in group 5 ( control +ve ) and group 8 which treated with AFT, HSCAS and YCW .The remaining recorded mortality rate were moderate.

A diet containing $400 \mathrm{mg} / \mathrm{kg}$ AFB1 severely affected body and relative liver weights in turkeys, while chickens showed no effect at this dietary concentration (Leeson et al., 1995). Liver relative weight was significantly increased only in birds that received 1,000 ppb of aflatoxins(Rauber et al.,2007). They also added that, mortality in their experiment was about $10.1 \%$. However, treatments that showed higher mortality were those that received 200 (18.7\%), 500 (8.3\%), and 1,000 $(37.5 \%) \mathrm{ppb}$ of aflatoxins, and they concluded that, mortality index had a strong correlation with aflatoxin doses. 
Table(5) \& Fig.(5): Effect of Aflatoxin and tested materials on Broiler liver weight and mortality rate of different groups

\begin{tabular}{|c|c|c|}
\hline Groups & Liver weight & Mortality \\
\hline $\mathbf{1}$ & $51.033 \pm 3.139^{3,5, /}$ & $0^{4,5,6, l, 8}$ \\
\hline $\mathbf{2}$ & $53.667 \pm 4.384^{3,5, /}$ & $0^{4,5,6, /, 8}$ \\
\hline $\mathbf{3}$ & $46 \pm 4^{1,2,4,6,8}$ & $0^{4,5,6,18}$ \\
\hline $\mathbf{4}$ & $53.4 \pm 2.425^{3,5, /}$ & $1.333^{1,57^{1,2,3,5,8}}$ \\
\hline $\mathbf{5}$ & $43.633 \pm 0.577^{1,2,4,6,8}$ & $4 \pm 1^{1,2,3,4,6,1,8}$ \\
\hline $\mathbf{6}$ & $52.667 \pm 0.577^{3,5, /}$ & $1 \pm 0^{1,2,3,5,8}$ \\
\hline $\mathbf{7}$ & $45.667 \pm 1.528^{1,2,4,6,8}$ & $1 \pm 0^{1,2,3,5,8}$ \\
\hline $\mathbf{8}$ & $54.633 \pm 2.315^{3,5, /}$ & $2.333 \pm .58^{1,2,3,4,5,6, /}$ \\
\hline
\end{tabular}

no.) with the group(s) no. which they significantly $(p<.05)$ different with it

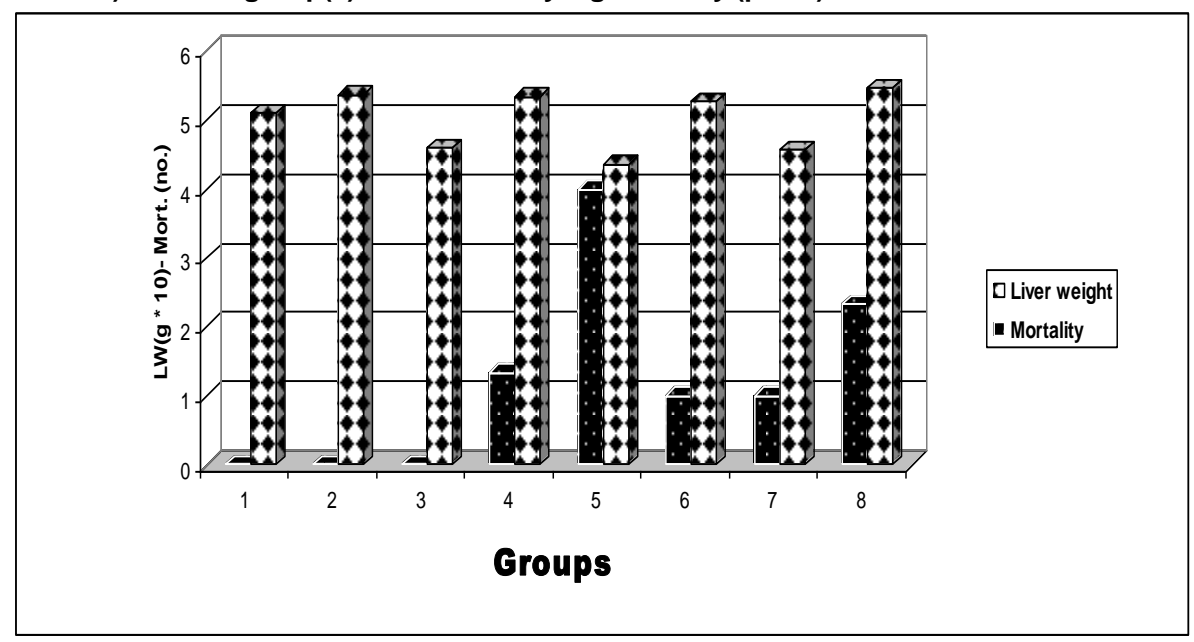

The elevation in body weight gain concomitant with decreased in liver weight which recorded herein in groups 3,7 which treated with YCW may regarded to unknown mode of action for YCW products in broiler chicken .

Residue of aflatoxin in litter of broiler of different tested groups is illustrated in Table (6) and Figure(6). As it is evident from data recorded that, the litter of broiler fed on aflatoxin free diet is free from aflatoxin residue, while the litter of broiler fed on AFT-contaminated diet containing variable levels of AFT- residue. AFT- residue levels in the previous groups were significantly differ. The highest level was in group 6 which treated with HSCAS singly ( $996.83 \mu \mathrm{g} / \mathrm{kg}$ dry matter), while the lowest was in group 7 , which treated with YCW only ( $108.033 \mu \mathrm{g} / \mathrm{kg}$ dry matter). The residue in litter of group 7 , which treated with the mixture of both (HSCAS + YCW ) was moderate $(331.7 \mu \mathrm{g} / \mathrm{kg}$ dry matter). This result strongly confirm the previous speculation which mentioned herein about the nature and mode of action of the tested detoxifier materials. 
Shebl, M.A. et al.

6

310 
In an experiment, $25 \mathrm{Hy}$-Line $\mathrm{W}-36$ hens, in their second production stage, 121 weeks old, were distributed in 3 groups placed in individual cages and 1 ration of $250 \mathrm{~g}$ of feed was given to each hen daily. Nine hens of the control group were fed with clean feed, without $\mathrm{AFB}_{1}$; the other 2 experimental groups, with 8 hens each, were fed with $2 \mathrm{AFB}_{1}$ concentrations: 30 and $500 \mu \mathrm{g} \cdot \mathrm{kg}^{-1}$. In litter samples, there were significant differences for $\mathrm{AFG}_{2}$ in the $500 \mu \mathrm{g} \cdot \mathrm{kg}^{-1}$ group. Poultry litter had traces of $A F M_{1}, A F M_{2}, A F P_{1}$, and AFL with no significant differences among treatments ( Cortes et al., 2010). They also added that, aflatoxin $\mathrm{B}_{1}$ prevalence in litter samples can cause damages in livestock because this mycotoxin reduces the digestibility of ruminant feed up to $67 \%$.

On the other hand ,the residue of of micro-elements $\mathrm{Al}, \mathrm{As}, \mathrm{Cd}, \mathrm{Pd}$, $\mathrm{Se}, \mathrm{Cu}, \mathrm{Fe}, \mathrm{Mn}, \mathrm{Zn}$ and macro-elements $\mathrm{k}, \mathrm{Na}, \mathrm{Mg}$ in broiler litter of different tested groups were illustrated in Table (7) and Figure(7). As it is evident from data recorded that, Al levels increased significantly in litter of groups 6,7,8 which treated with AFT- treated ,and both detoxifier materials, singly or in combination. Also ,in litter of groups 6,8 which treated with HSCAS, Significant high levels of $\mathrm{zn}, \mathrm{k}$ and $\mathrm{Na}$ were recorded. The addition of both detoxifier to feed, elevate level of Se in broiler litter.

There is a lack age in the information available about the effect of AFT or the detoxifier materials such as HSCAS or YCW on the pattern of metal in poultry meat and litter. The major route of entry of most elements into and out the body is through the diet (Surtipanti et al 2001). In the shadow of this, with the fact that HSCAS have ability to lose and gain water, and to exchange constituent cations ( Mumpton and Fishman , 1977 ), beside the unknown mode of action of YCW products in broiler, the disturbance in the levels of different metals in broiler latter of different groups can explained .

The present study concluded that, no clear improvements in the tested parameters were recorded after the the contaminated diets were incorporated with the recommended dose of HSCAS and YCW, singly or in combination, during aflatoxicosis. It also, in part, focused the unwanted behavioral of adsorbents in animal production, and submitted that the using of this materials in animal feed must be restricted, because of its unknown action, as well as its indirect dangerous effect in livestock. 
Shebl, M.A. et al. 


\section{REFERENCES}

AOAC (2005). Association of Official Analytical Chemists of Official Methods of Analysis. $18^{\text {th }}$ ed,. Washington. D.C.

Agemain ,H. ; Sturtevant, D. P. and Austen , K. D. (1980) . Simultaneous acid extraction of trace metals from tissues by hot block digestion and determination by Atomic Absorption Spectrometry. Analyst, 105-125.

Aguilar-Uscanga, B., and François, J. M. (2003) . A study of the yeast cell wall composition and structure in response to growth conditions and mode of cultivation. Lett. Appl. Microbiol. 37:268-274.

Ali, M. N. ; Qota ,E. M. A. ; Hassan ,R. A. and Abou-Elmaged ,M. K. (2006). Novel methods of detoxification of aflatoxin B1 in contaminated Local Laying hen diets. Egypt Poult. Sci., 26 (III) : 911-940.

Arafa, A. S., Bloomer ,R. J.; Wilson,H. R. ; Simpson,C. F. and Harms ,R. H. (1981). Susceptibility of various poultry species to dietary aflatoxin. $\mathrm{Br}$. Poult. Sci., 22:431-436.

Badria, F.A. (1996): Amultidscplinary study to monitor mycotoxins in Egypt. J. Toxicol. Toxin Review., 15 (3): 251-272.

Battacone, G.; Nudda, A. ; Palomba , M. ; Mazzette, A. and Pulina, G. (2009). The transfer of aflatoxin M1 in milk of ewes fed diet naturally contaminated by aflatoxins and effect of inclusion of dried yeast culture in the diet. J. Dairy Sci , 92:4997-5004 .

Baurhoo, B.; Phillip, L and Ruiz-Feria, C. A. (2007). Effects of purified lignin and mannan oligosaccharides on intestinal integrity and microbial populations in ceca and litter of broiler chickens. Poult. Sci., 86:10701078.

CAST (1989). Council for Agricultural Science and Technology. Mycotoxins: Economic .

CAST (2003). Council of Agricultural Science and Technology. Mycotoxins: risks in plant, animal and human systems. CAST, Ames, IA. p. 139.

Cole, R. J., and Cox ,R. H. (1981). The aflatoxins. Pages 1-66 in Handbook of Toxic Fungal Metabolites. Academic Press, New York, NY.

Cortés,G. M. ; Carvajal, I. ;Méndez-Ramírez, E. ;Ávila-González, N. ;ChilpaGalván, P. ;Castillo-Urueta* and Flores ,C. M. (2010). Identification and quantification of aflatoxins and aflatoxicol from poultry feed and their recovery in poultry litter. Poult. Sci., 89: 993-1001.

Coulombe Jr., R.A.(1993). Biological action of mycotoxins. Journal of Dairy Science, 79: 880-891.

Davegowda, G., and Murthy ,T. N. K. (2005). Mycotoxins, their effects in poultry and some practical solutions. Pages 25-56 in Mycotoxins Blue Book. D. E. Diaz, ed. Nottingham University Press, Nottingham, UK.

Davis, N.D. Dionber, U.L. and Dridge, D.W. (1966). Production of Aflatoxin B and $\mathrm{G}_{1}$ by Asperquillus flavous in a semisynthetic medium, Applied Microbiology, 14, 378-380. 
El-Tahan, F.H.; El-Tahan ,M.H. and Shebl ,M.A (2000).Occurrence fo aflatoxins in cereal grains from four Egyptian governorates. Nahrung, 44(4): 279-280.

Eurasyp (2007):. Yeast products: Yeast cell wall. http://www.eurasyp.org/public.levure.ecorce.screen\#composants Accessed July 2008.

Fernandez, A., Verde,M. ; Gomez,T. J. ; Gascon,M. and Ramos ,J. J. (1995). Changes in the prothrombin time, haematology and serum proteins during experimental aflatoxicosis in hens and broiler chickens. Res. Vet. Sci., 58:119-122.

Giacomini, L., Fick,F. A.; Dilkin,P. ; Mallmann,C. A. ; Rauber,R. H. and Almeida, C. (2006). Desempenho e plumagem de frangos de corte intoxicados por aflatoxinas. Ciênc. Rural, 36:234-239.

Giambrone, J. J., Diener,U. L.; Davis,N. D.; Panangala,V. S. and Hoerr ,F. J. (1985): Effects of aflatoxin on young turkeys and broiler chickens. Poult. Sci., 64:1678-1684.

Hamilton, P. B., Tung,H. T. ; Harris, J. R. ; Gainer,J. H. and Donaldson ,W. E. (1972). The effect of dietary fat on aflatoxicosis in turkeys. Poult. Sci., $51: 165-170$.

Hassan, R. A. (2006). Capability of mannan-oligosaccharide (Bio-Mos(R)), organic selenium and Hydrated Sodium Calcium Aluminosilicate to detoxify Aflatoxicosis for Growing Local Chickens. Egypt Poult. Sci., 26 (II): 495-511.

Heath, D. (1995). An introduction to experimental Design and Statistics. For Biology, UCL Press Limited, University College. London, England.

Hooge , D.M. (2004). Turkey pen trials with dietary mannoligosaccharide . Meta-analysis, 1993-2003 . Inter. J. Poult. Sci., 3:179.

Hsieh, D.P.H. (1983). Metabolism and transmission of mycotoxins. Proc. Int. Symp Mycotoxins, Cairo, Egypt, PP. 151-165.

Hussein, H. S., and Brasel ,J. M. (2001).Toxicity, metabolism and impact of mycotoxins on humans and animals. Toxicology 167:101-134.

Joffe, A. Z. (1970). Feeding tests with ducklings, turkey chicks and rabbits and the effects of aflatoxin on these animals. Mycopathol. Mycol. Appl., 40: 49-61.

Lanza, G. M.; Washburn,K. W. and Wyatt ,R. D. (1980). Variation with age in response of broilers to aflatoxin. Poult. Sci. 59:282-288.

Ledoux, D. R. ; Rottinghaus, G. E. ; Bermudes, A. J. and Alonso-Debolt, M. (1999). Efficacy of a Hydrated Sodium Calcium Aluminosilicate to Ameliorate the Toxic effects of Aflatoxin in Broiler Chicks. Poultry Sci., 78: 204-210.

Leeson, S., Diaz,G. and Summer, J. D. (1995). Aflatoxins. In Poultry Metabolic Disorders and Mycotoxins. University Books, Guelph, Canada. Pages :249-298

Mumpton , F. A. and Fishman , P. H. (1977). The Application of Natural Zeolites in Animal Scince and Aquaculture. J. Animal Sci., 45(5):11881203.

Mycotoxins. University Books, Guelph, Ontario. pp. 249-280.

Park, D.L. (1993): Controlling aflatoxin in food and feed. Food technology (USA), 47(10): 92-96. 
Quist, C. F., Bounous, D. I.; J Kilburn,. V. ; Nettles,V. F. and Wyatt, R. D. (2000). The effect of dietary aflatoxin on wild turkey poults. J. Wildl. Dis., 36: 436-444.

Rauber, R. H.; Dilkin, P. ; Giacomini, L. Z. ; Araújo de Almeida ,C. A. and Mallmann ,C. A.(2007). Performance of turkey poults fed different Doses of Aflatoxins in the Diet. Poult. Sci., 86:1620-1624.

Rawal,S. ; Kim, J. E. and Coulombe Jr. R. (2010). Aflatoxin B1 in poultry: Toxicology, metabolism and prevention. Research in Veterinary Science. journal homepage: www.elsevier.com/locate/rvsc .

Richard, J.L., Stubblefield, R.D., Lyon, R.L., Peden, W.M., Thurston, J.R., Rimler, R.B.(1986). Distribution and clearance of aflatoxins B1 and M1 in turkeys fed diets containing 50 or $150 \mathrm{ppb}$ aflatoxin from naturally contaminated corn. Avian

Roos, A. H. ; H. J. Van der Kamp and E. C. Marley (1997). Comparison of immununeaffinity columns for the determination of aflatoxin in animal feed an maize. Mycotoxin Research, $13: 1-10$.

Rosen, G. D. (2007). Halo-analysis of the efficacy of Biol.-Mos ${ }^{\circledR}$ in broiler nutrition. Br. Poult. Sci., 48:21-26.

Santin, E., Maiorka, A. and Macari ,M. (2001). Performance and intestinal mucosa development of broilers chickens fed diets containing Saccharomyces cerevisiaes cell wall. J. Appl. Poult. Res., 10:236-244 .

Scheideler, S. A. (1993). Effect of Various types of Aluminosilicates and Aflatoxin B1 on aflatoxin toxicity, chick performance and miniral status. Poultry Sci., 27:282-288.

Selim, M.I.; Popendorf ,W. ; Ibrahim ,M.S. ; El-Sharkawy ,S. and El-Kashory, E.S. (1996). Aflatoxin $B_{1}$ in common Egyptian foods. J. AOAC Inter, 79 (5): 1124-1129.

Spring, P.; Wenk, C.; Dawson, A. K. and Newman, E. K. (2000).The effects of dietary mannanoligosaccharides on cecal parameters and the concentrations of enteric bacteria in the ceca of Salmonella-challenged broilers chicks. Poult. Sci., 79: 205-211.

Stanley, V. G.; Brown, C. and Sefton ,A. E. (2000). Comparative evaluation of a yeast culture, mannanoligosaccharide and an antibiotic on performance of turkeys. Poult. Sci., 79(1):117.

Surtipanti, S. ; Suwirma, S. ; Yumaiarti , S. and Mellawati , Y. (2001). Determination of Heavy Metals in meat, Intestine, Liver Eggs and Chicken using Neutron Activation Analysis and Atomic Absorption spectrometry. http://www.digilib.batan.go.id/atom-indonesia/ Accessed July 2002.

Tenorio Arvide,M. G.; Mulder, I. ; Barrientos Velazquez , A.L. and Dixon , J. B. (2008). smectite clay adsorption of aflatoxin vs. octahedral composition as indicated by ftir. Clays and Clay Minerals, 56(5) p. 571578.

Zhang, A. W., Lee, B. D. Lee; S. K. ;. Lee, K. W ; An, G. H.; Song, K. B. and Lee; C.H. (2005).Effects of yeast (Saccharomyces cerevisiae) cell components on growth performance, meat quality, and ileal mucosa development of broilers chicks. Poult. Sci., 84:1015-1021. 
التسمم الأفلاتوكسينى فى الاجاج:

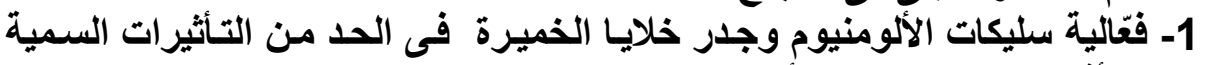

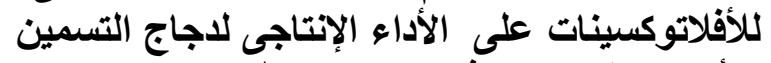

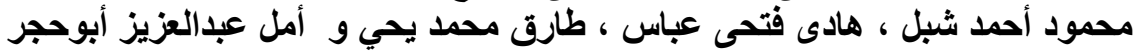

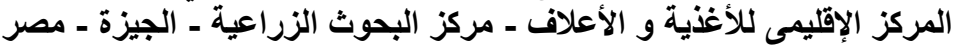

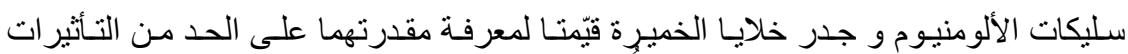

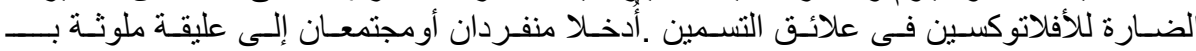

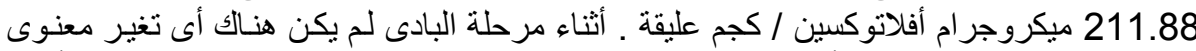

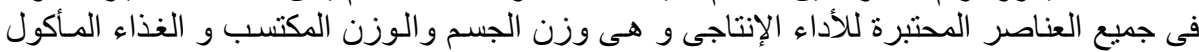

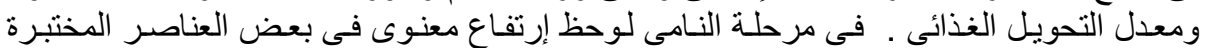

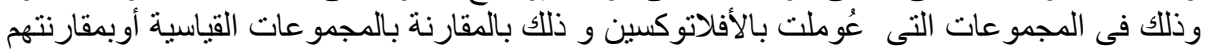

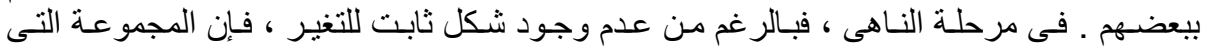

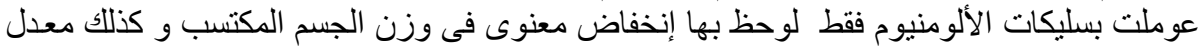

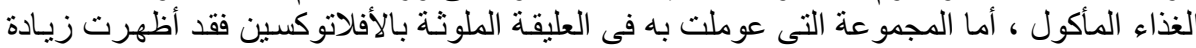

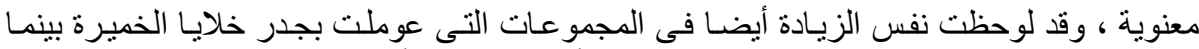

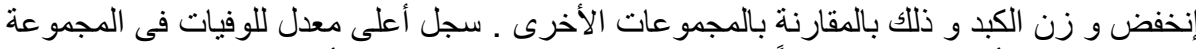

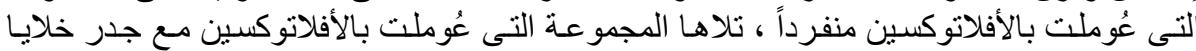

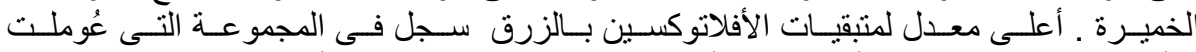

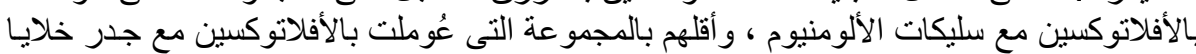

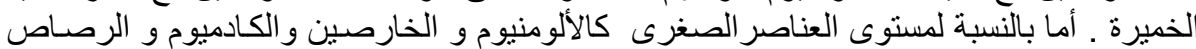

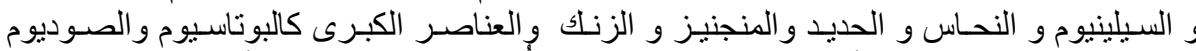

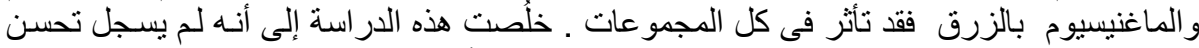

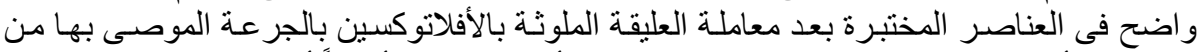

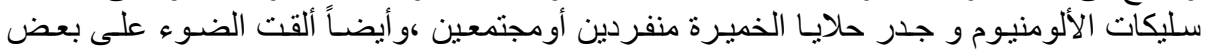

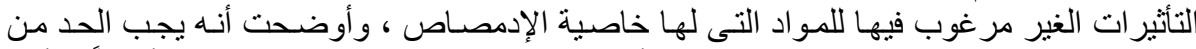

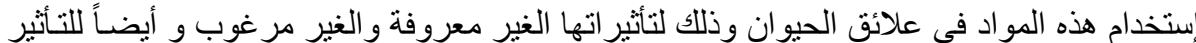

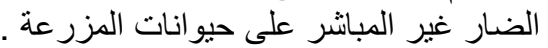

كلية الزراعة - جامعة المنصورة كلية الزراعة - جامعة الأزهر

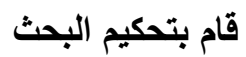

أ.د / محمد محمد الثناوى اسماعيل أ.د / طارق محمد يونس محم الدن 
J. Animal and Poultry Production, Mansoura Univ., Vol. 1 (7), July, 2010 
Table( 6 ) \& Fig $(6)$ : Residue of Aflatoxin in litter ( $\mu \mathrm{g} / \mathrm{kg}$ dry matter ) of Broiler of different tested groups

\begin{tabular}{|c|c|c|c|c|c|}
\hline \multirow[b]{2}{*}{ Group } & \multicolumn{4}{|c|}{ Type of Aflatoxin } & \multirow[b]{2}{*}{ Total AFT } \\
\hline & $\mathrm{AFB}_{1}$ & $\mathrm{AFB}_{2}$ & $\mathrm{AFG}_{1}$ & $\mathrm{AFG}_{2}$ & \\
\hline 1 & $0^{5,6,7,8}$ & $0^{5,6,1,8}$ & $0^{5,6,7,8}$ & $0^{6,8}$ & $0^{5,6,1,8}$ \\
\hline 2 & $0^{5,6,7,8}$ & $0^{5,6,1,8}$ & $0^{5,6,1,8}$ & $0^{6,8}$ & $0^{5,6,7,8}$ \\
\hline 3 & $0^{5,6,1,8}$ & $0^{5,6,1,8}$ & $0^{5,6,1,8}$ & $0^{6,8}$ & $0^{5,6,7,8}$ \\
\hline 4 & $0^{5,6,1,8}$ & $0^{5,6,7,8}$ & $0^{5,6,1,8}$ & $0^{6,8}$ & $0^{5,6, /, 8}$ \\
\hline 5 & $24 \pm 2^{1,2,3,4,6, /, 8}$ & $33.4 \pm 2.946^{1,2,3,4,6,1,8}$ & $536.85 \pm 32.346^{1,2,3,4,6, /, 8}$ & $0^{6,8}$ & $587.333 \pm 32.578^{1,2,3,4,6,1,8}$ \\
\hline 6 & $13.033 \pm 2.196^{1,2,3,4,5,7,8}$ & $10.333 \pm 2.517^{1,2,3,4,5}$ & $948.853 \pm 42.947^{1,2,3,4,5,1,8}$ & $3.496 \pm .906^{1,2,3,4,5, /, 8}$ & $996.833 \pm 105.04^{1,2,3,4,5,1,8}$ \\
\hline 7 & $3.933 \pm .493^{1,2,3,4,5,6,6,8}$ & $13.352 \pm 2.426^{1,2,3,4,5}$ & $89.267 \pm 6.133^{1,2,3,4,56,8}$ & $0^{6,8}$ & $108.033 \pm 7.027^{1,2,3,4,5,6,8}$ \\
\hline 8 & $18.733 \pm 4.026^{1,2,3,4,5,6,7}$ & $10.167 \pm 2.35^{1,2,3,4,5}$ & $316.2 \pm 22.193^{1,2,3,4,5,6,7}$ & $6.3 \pm .608^{1,2,3,4,5,6, /}$ & $331.7 \pm 28.446^{1,2,3,4,5,6, /}$ \\
\hline
\end{tabular}

, means within the same column are labeled (superscript no.) with the group(s) no. which they significantly $(p<.05)$ different with it

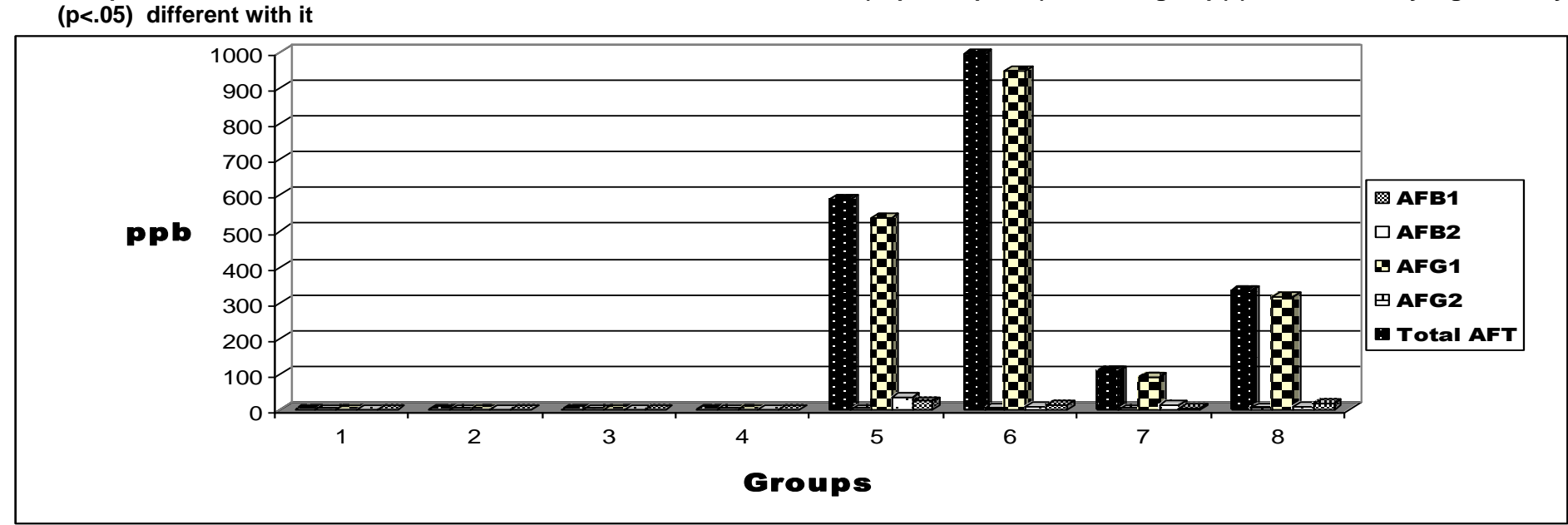


J. Animal and Poultry Production, Mansoura Univ., Vol. 1 (7), July, 2010

Table( 7 ) \& Fig( 7 ) : Residue of some elements in Litter of Broiler of different tested groups

\begin{tabular}{|c|c|c|c|c|c|c|c|c|c|c|c|c|}
\hline \multirow[b]{3}{*}{ Groups } & \multicolumn{12}{|c|}{ Typeandunit of elements } \\
\hline & \multicolumn{9}{|c|}{ Microedements (mg/kgDrymatter) } & \multicolumn{3}{|c|}{ Macroedements(gkg Drymatter) } \\
\hline & A & As & $\mathbf{C d}$ & $\mathbf{P b}$ & $\mathrm{Se}$ & $\mathrm{Cu}$ & $\mathrm{Fe}$ & Mn & Zn & $\mathrm{K}$ & $\mathrm{Na}$ & $\mathrm{Mg}$ \\
\hline 1 & $\begin{array}{c}474.34^{65} \\
\pm 81.52\end{array}$ & $\begin{array}{c}147.33^{234567} \\
\pm 34.15\end{array}$ & $\begin{array}{l}0.00 \\
\pm 0\end{array}$ & $\begin{array}{c}19.64^{24566 / 8} \\
\pm 4.69\end{array}$ & $\begin{array}{l}0.077^{3 / 15} \\
\pm 0.017\end{array}$ & $\begin{array}{l}58.590 \\
+723\end{array}$ & $\begin{array}{l}1111.45^{6} \\
+301.37\end{array}$ & $\begin{array}{c}449.77^{244} \\
+4578\end{array}$ & $\begin{array}{c}260.95^{466 / 8} \\
+529\end{array}$ & $\begin{array}{c}20.01^{2469} \\
+218\end{array}$ & $\begin{array}{l}3.18^{26} \\
+0.99\end{array}$ & $\begin{array}{c}0.00 \\
\pm 0\end{array}$ \\
\hline & $406.17^{6 / 8}$ & $54.03^{1,93}$ & 0.00 & $1299^{1,6 / 8 / 8}$ & $0.109^{3 / 245}$ & 56.100 & $1103.67^{6}$ & $349.07^{156 / 3 / 8}$ & $248.2^{466 / 18}$ & $34,4^{1,3,4608}$ & $5.13^{13,435}$ & 0.00 \\
\hline 2 & \pm 51.03 & \pm 1215 & \pm 0 & \pm 3.00 & \pm 0.025 & \pm 10.36 & \pm 161.22 & \pm 4273 & \pm 46.48 & \pm 3.34 & \pm 0.78 & \pm 0 \\
\hline . & $469.64^{63}$ & $\begin{array}{l}86.74^{1} \\
+1450\end{array}$ & 0.0 & $\begin{array}{l}9.43^{1, / / 8} \\
+246\end{array}$ & $0.219^{1 / 2456 / 8}$ & 64.750 & $863.45^{6}$ & $359.37^{156}$ & $\begin{array}{c}225.59^{456 / 8} \\
+5045\end{array}$ & $26.67^{26,68}$ & $3.27^{26}$ & 0.00 \\
\hline 4 & $\begin{array}{l}431.91^{69} \\
\pm 6256\end{array}$ & $\begin{array}{l}81.66^{18} \\
\pm 11.06\end{array}$ & $\begin{array}{l}0.0 \\
\pm 0\end{array}$ & $\begin{array}{c}10.06^{156 / 8} \\
\pm 1.9\end{array}$ & $\begin{array}{c}0.341^{12356 / 8} \\
\pm 0.052\end{array}$ & $\begin{array}{r}73.620 \\
\pm 1258\end{array}$ & $\begin{array}{l}928.33^{6} \\
\pm 215.13\end{array}$ & $\begin{array}{c}364.17^{156} \\
\pm 48.17\end{array}$ & $\begin{array}{c}149.03^{12368} \\
\pm 30.46\end{array}$ & $\begin{array}{c}30.14^{15, / 8} \\
\pm 3.49\end{array}$ & $\begin{array}{l}3.87^{26} \\
\pm 0.99\end{array}$ & $\begin{array}{l}0.00 \\
\pm 0\end{array}$ \\
\hline 5 & $\begin{array}{c}410.35^{6 / 8} \\
\pm 5252\end{array}$ & $\begin{array}{l}83.01^{18} \\
\pm 8.20\end{array}$ & $\begin{array}{l}0.0 \\
\pm 0\end{array}$ & $\begin{array}{c}4.54^{1234} \\
\pm 1.5\end{array}$ & $\begin{array}{c}0.475^{1234468} \\
\pm 0.100\end{array}$ & $\begin{array}{r}59.250 \\
\pm 11.87\end{array}$ & $\begin{array}{l}1127.67^{6} \\
\pm 283.87\end{array}$ & $\begin{array}{l}446.3^{334} \\
\pm 44.11\end{array}$ & $\begin{array}{c}146.83^{12368} \\
\pm 3204\end{array}$ & $\begin{array}{c}13.46^{23468} \\
\pm 230\end{array}$ & $\begin{array}{l}3.54^{26} \\
\pm 0.48\end{array}$ & $\begin{array}{l}0.00 \\
\pm 0\end{array}$ \\
\hline 6 & $\begin{array}{c}764.12^{12345 / 7} \\
\pm 107.18\end{array}$ & $\begin{array}{c}107.6^{127} \\
\pm 25.4\end{array}$ & $\begin{array}{l}0.0 \\
\pm 0\end{array}$ & $\begin{array}{l}5.46^{124} \\
\pm 1.38\end{array}$ & $\begin{array}{c}0.051^{345} \\
\pm .006\end{array}$ & $\begin{array}{l}77.35^{78} \\
\pm 9.79\end{array}$ & $\begin{array}{c}1683.33^{12345 / 7} \\
\pm 348.19\end{array}$ & $\begin{array}{c}450.87^{234} \\
\pm 39.89\end{array}$ & $\begin{array}{c}405.36^{123457} \\
\pm 49.29\end{array}$ & $\begin{array}{c}44.96^{12345 / 7} \\
\pm 5.86\end{array}$ & $\begin{array}{c}5.35^{13.457} \\
\pm 0.31\end{array}$ & $\begin{array}{l}0.00 \\
\pm 0\end{array}$ \\
\hline 7 & $\begin{array}{l}570.00^{256} \\
\pm 108.17\end{array}$ & $\begin{array}{l}67.16^{1,98} \\
\pm 11.76\end{array}$ & $\begin{array}{l}-0 \\
\pm 0\end{array}$ & $\begin{array}{c}3.27^{1234} \\
\pm 0.78\end{array}$ & $\begin{array}{l}0.073^{345} \\
\pm 0.026\end{array}$ & $\begin{array}{r}54.57^{7} \\
\pm 16.75\end{array}$ & $\begin{array}{c}1186.75^{6} \\
\pm 280.2\end{array}$ & $\begin{array}{l}434.97^{2} \\
\pm 50.85\end{array}$ & $\begin{array}{c}125.63^{12368} \\
\pm 23.17\end{array}$ & $\begin{array}{c}20.73^{2468} \\
\pm 4.53\end{array}$ & $\begin{array}{l}3.97^{6} \\
\pm 0.57\end{array}$ & $\begin{array}{l}0.00 \\
\pm 0\end{array}$ \\
\hline 8 & $\begin{array}{c}643.33^{12345} \\
\pm 136.14\end{array}$ & $\begin{array}{c}121.73^{24,7} \\
\pm 36.17\end{array}$ & $\begin{array}{l}0.0 \\
\pm 0\end{array}$ & $\begin{array}{l}3.1^{1234} \\
\pm 0.72\end{array}$ & $\begin{array}{l}0.11^{345} \\
\pm 0.021\end{array}$ & $\begin{array}{l}53.00^{6} \\
\pm 15.41\end{array}$ & $\begin{array}{l}1274.440 \\
\pm 355.57\end{array}$ & $\begin{array}{l}437.63^{2} \\
\pm 46.61\end{array}$ & $\begin{array}{c}345.27^{12349} \\
\pm 41.27\end{array}$ & $\begin{array}{c}44.59^{12 / 4,7} \\
\pm 5.06\end{array}$ & $\begin{array}{l}4.190 \\
\pm 0.67\end{array}$ & $\begin{array}{l}0.00 \\
\pm 0\end{array}$ \\
\hline
\end{tabular}

Data expressed as mean \pm SD , means within the same column are labeled (superscript no.) with the group(s) no. which they significantly (p<.05) different with it
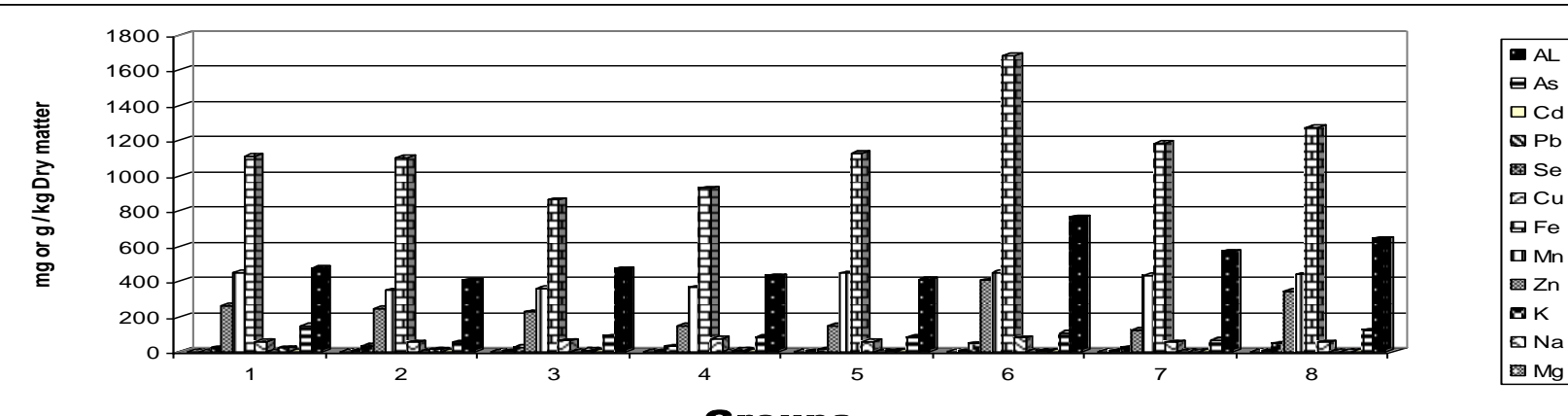

Groups 